in India we possess almost unrivalled opportunities for examining and analysing the atmospheric column in all its parts, and that India proper, the Bay of Bengal and Burma, constitute a region which, for the purposes of one branch at least of meteorological science, demands to be taken and treated as a whole. The actual state of the case, on the other hand, is that for administrative purposes, British India is divided into eight principal districts or provinces, viz., Bengal, Madras, Bombay, N.W. Provinces, Oude, Panjab, Central Provinces, and Burma; and in each of these, except Burma, is a separate local system of observation, with its own independent head, and very little communication with one another.

ON the and May, two days before the full moon, a complete Iunar halo was observed at Clifton by Mr. George F. Burder,

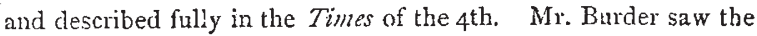
two halos, the large one and the small one, the larger being very difficult to be seen. A paraselenic circle, having the zenith for its centre, was also observed, and mock moons, or paraselutues, four in number, were seen at the intersection of the halo with the paraselenic circle. This appearance, as usual, was followed by very bad weather. It is produced, as demonstrated by the French natural philosophers of the eighteenth century, by foating particles of ice; and the light from the moon being considerable, the phenomenon was observed in all its glory.

Mr. T. Login's reports on the experimental cultivation of cotton at Camp Bahalgurh in the Valley of the Jumra, are exceedingly satisfactory. Althongh the crops were damaged by floods and by late frosts, the yield of clean cotton has been at the rate of $307 \frac{1}{2}$ lbs. per acre, or from four to five times the average yield in India. Mr. Login attributes this result in great measure to his practice of irrigating the fields in the afternoon or night, rather than in the mid-day, believing that the combined action of light and heat on stagnant water makes it uncler almost all circumstances injurious to plants.

OF the many fresh-water fish characteristic of the continent of North America, comparatively few, with the exception of mem bers of the salmon and trout family, are of sufficient economical value to make it expedient to introduce them into regions where, they do not naturally occur. This transfer has been made to a very disastrous extent in the case of the pike (Esox), which although multiplying rapidly, is at the same time the determined foe of all other kinds of fish, and soon almost exterminates them from the waters which it inhabits. For this reason, some States have passed laws prohibiting, under severe penalties, except by direct permission of the Commissioners of the Fisheries, any transfer of the species in question to new localities. There is, however, one fish that is of great value, and which can be introduced without as much doubt of the propriety of the act as exists in regard to the pike. We refer to the black bass (Grystes salmoides). This inhabits, in one variety or another, the basin of the great lakes of the Mississippi Vallty, and the upper waters of the streams of the south Atlantic coast as far north as the James River. Within a few years it has been transferred with success to streams previously uninhabited by it-to the Potomac, for one, where it is now extremely abundant. During the past summer some public-spirited gentlemen of Philadelphia collected among themselves a fund to stock the Delaware with this noble fish, and obtained about seven hundred, principally in the vicinity of Harper's Ferry. These were carried alive in large tanks to the Delaware, and deposited in that stream at Easton, about two hundred of the number dying by the way. The same party of gentlemen propose to use a surplus fund in their hands in experimenting upon the restocking of the river with shad and salmon.

THE white sugarcane of Cuba has been tried in Columbia and found more productive than the local variety called Cinia.

\section{REPORT ON THE DESERT OF THE TIH*}

THE following report has been sent to the Vice-Chancellor of Cambridge by Mr. C. F. Tyrwhitt Drake, who received a grant from the University for the purpose of investigating the natural history of the Tíh. He spent several months in the district, accompanied by Mr. E. H. Palmer (late of the Sinai Survey), who was travelling on behalf of the Palestine Explora. tion Fund :-

I have now the honour to lay before you a report of my work during last winter in the "Badiet et Tíh," or Wilderness of the Wandering. As this desert had been only partially, and even then superficially examined, I shall give, firstly, a short account of the ronte we took and of the general physical features of the country ; and, secondly, the various traditions of beasts and birds which are current amongst the Arabs. Many of these are curious, from their similarity to Western tales; and others, though seemingly foolish in themselves, are not without interest, as illustrating the beliefs and folk-lore of the Bedawín. These stories are not so numerous as $I$ found them to be in former journeys amongst Arabs inhabiting more fertile tracts, for the Desert of the Tih is in truth "a great and terrible wilderness." The last winter, too, was one of unusual drought even in those parched regions, and the scattered tribes of Arabs who live there experienced great difficulty in finding pasture for the hercls of camels and goats which exist in considerable numbers in some districts.

The supply of water is very scanty and variable, as springs are extremely rare, and most of the water is obtained from "Themail," or pits dug in the gravelly beds of wadies, and similar situations into which the water filtrates. The water thus obtained is very bad, being impregnated either with mineral salts or lime, to say nothing of the quantity of earthy and animal matter held in suspension by its being constantly stirred up for the daily use of the Arabs and their flocks, who naturally collect in the neighbourhood of any place where water is to be had. This want of water was the greatest drawback to the satisfactory exploration of the country : want of food may be contended with, obstructive Bedawin may be quieted, and trackless mountains crossed, but the absence of water renders a country impracticable, especially to those who travel as lightly laden as we did, dispensing with the usual suite of dragoman and servants. Picturesque and desirable as a large retinue and guard of wild Arabs may appear to some persons, had we indulged in these impedimenta, I feel convinced that we should never have got through the country by any but the ordinary route. In these districts fertility is slowly but steadily being driven northwards, for various traces of cultivation and dwellings show that the rainfall must formerly have been plentiful and regular, for surely as tillage and the consequent vegetation decreases, so will the rain-stpply diminish till the land has become an irreclaimable waste.

The manner in which gardens may be macle and will afterwards sustain themselves, is well shown in those which still flourish at Sinai, notwithstanding the neglect of the present degraderl inmates of the convent

Even in those parts of the Tíh near El Aujeh and Wady el Abyadh which, from internal evidence, must at one time, and that within our era, have supported a large settled population, so desolate is the general aspect, that, to a castal observer, the country would seem to be and always to have been an utter waste. That they were so always is, however, at once negatived by the existence of several ruined cities surrounded by the remains of extensive gardens and vineyards ; of these, the walls alone remain to tell their tale. The vineyards are clearly to be traced on the low hills and rising grounds by the regular heaps and "swathes" of black flints, with which the chief part of the district is covered, and which still retain the name of "Teleilat el 'Aneb". or grapemounds. These facts are of great importance as showing that the objections to fixing certain localities-mentioned in Scripture as abounding in pasturage-in what is now completely desert, may be set aside as worthless. I consider too, that the southern limit of the Promised Land, at the time of the Israelitish invasion, must be placed as far south as Wady El Abyadh. This would remove many difficulties hitherto met with in the satisfactory identification of Kadesh. Though I have not space to enter fully into the question here, I may say that there is strong evidence in favour of fixing that much-disputed locality at Ain Gadis (first dis-

* A map to illusirate this paper is printed in the "Quarterly Toumal o the Palestine Exploration Fund "for Jantuary. 
covered by Mr. Rowlands, though he seems to confuse it with Ain El Gudeirat). Many facts support this supposition, for instance, the suitability as a strategic position for a camp of long duration. There is abundance of water there even at the present day, and springs are found at Ain Muweilah to the north and Biyar Maayin to the south. The probability is great that a large host like the Israelites, encumbered with their families and herds, would take the easy route by the open country to the west of the Azazimeh mountains in preference to the barren and rugged passes south-west of the Dead Sea.

The clesert of the Tíh consists of a succession of limestone plateaux intersected by several wadies, of which the most important are W. El Arísh, which is joined near Nakhl by W. Rowag, W. Garaiyeh, with its tributaries Mayin, Jerur, Muweileh, W. El Ain, which runs into W. El Abyadh, W. Rehaibeh and W. Seba, which drain into the Mediterranean. W. Ghamr and 'W. Jeráfeh - the names of which have been interchanged by former travellers-fall into the northern slope of the Arabeh, and so run into the Dead Sea, as also do Wadies Murreh, Maderah, and Figreh, which debouch into the Ghor es Sáfi.

The southernmost limit is Jebel el Rálah and Jebel el Tín on he S. W., and Jebel el'Ejmeh on the S. and S.E., which together form a cliff running from Suez to Akabah, and projecting into the peninsula of Sinai much in the same way as that peninsula pro. jects into the Red Sea. The heiglit of this cliff at its most elevated point - on Jebel el 'Ejmeh -is about 4, 200 feet above the sea, and from its summit the ground descends north-westwards.

To the N.E. of the Tíh rises a third steppe or promontory, its northern portion corresponding to the "Negeb" or south-country of Scripture, its southern part bearing the name of Jebel Magráh, sometimes also called "the mountains of the Azázimeh," from the tribe of Arabs which inhabits it. To the S.E. of this mountainous region we came upon the only bed of sandstone which occurs throughout the whole country. It belongs to the same formation (New Red sandstone) as that at Petra and the lower strata of the Dead Sea basin.

Having carefully considered the best means of thoroughly examining the Tíh plateau, Mr. Palmer and myself cletermined to proceed along the base of Jebel el Tíh, and leaving to the west the Nagbs Emreíkheh and er Rákineh-the passes on the orclinary routes for travellers proceeding northwards from Mount Sinai - io cross Jebel el'Ejmeh wherever it might prove practicable, and thus proceed through a hitherto untraversed clistrict to Nakhl, where we had established a depôt of provisions, and where we should have to make artangements with a different tribe of Arabs for carrying our baggage northwards.

This plan was carried out, and we entered the Tih by the Nagb el Mirád on January I2, I870, From the summit of the clifffor Jebel el 'Ejmeh has no pretensions to be called a mountain-a-a magnificent view is obtained of the Sinaitic peninsula. The range itself is composed of mountain limestone, so worn and broken by the action of frost and weather that the hills are covered with fine detritus, which, after rain, would produce some herbage, but when we were there only a few dried-up, stunted bushes were to be seen, which here as elsewhere in the desert supply good and abundant fuel.

From Jebel el'Ejmeh the steep, bleak, waterworn hills gradually slope down and fall away into the great plains, or rather, low plateaux, which stretch across to the Mediterranean. The sameness of outline and dreariness of this country is something terrible: the few shrubs that exist are grey or brown, and seemingly withered and dead; no animal life enlivens the scene--at times perhaps a stray vulture or raven may be seen sailing far away in the blue sky, a frightened lizard will start from beneath one's feet, or a small flight of locusts be disturbed from their scanty meal on some "retem bush." Water on the road there was absolutely none; a supply for four days had to be carried from El Biyár, a well strongly impregnated with Epsom salts, and lying a few miles to the south of Nagb el Mirád.

Under these conditions we can scarcely expect to meet with many signs of life. Judging from the numerous cairns and other primeval remains, this district must at one time have been populous. Wearily did I tramp day after day, gun in hand, but I was seldom rewarded with any thing more than a stray beetle or lizard, and now and then some small desert bird, and on very rare occasions a hare or snake.

As from former experience we had found that it was impossible to work a country thoroughly wheir mounted, we only employed enough camels to carry our baggage. The camel-drivers acted as guides, and, to a certain extent, as attendants, for we took no ser- vants whatever. This added to our already heavy work, yet it en abled us to get on much more satisfactorily with the various Arab tribes than we could otherwise have done.

From the Nagb el Mírád our course lay down Wady Rouâg, which takes its rise in the highest part of Jebel el 'Ejmeh, about eighteen miles east of the head of Wady el Arísh, with which it holds a nearly parallel course till it joins it at a short distance to the north-east of Nakhl. The district between Wady el Arish and Wady Rowág is drained by W. Ghabiyeh, which falls into the latter about twenty-five miles from the Nagb el Mirâd ; after this junction the country becomes open and comparatively level. Here the ground is almost as hard as a macadamised road, and is covered with a layer of small, black, polished flints, which glisten in the sun as though they were wet. This polish must be attributed to the dust and grit kept in motion by the almost incessant winds, which are frequently very violent. Many of the monuments in Egypt bear witness to the destructive action of the grit. In this desert sand is almost unknown. There are only two or three sandy tracts, and these may be traversed in a few hours at most. The largest sandy district we had to cross was the Rumeilet Hámed, to the north of Khalasah (the ancient Elusa) where the prevailing north-west winds have formed extensive dunes. This sand, however, seems to have been entirely brought from the coast.

On arriving at Nakhl we found a small fort with wells and cisterns. In this dreary spot, encompassed by glaring white hills, a few miserable soldiers are maintained by the Egyptian Govern. ment for the protection of the Haij caravan, the place being halfway between Suez and Akabah. Here we were obliged to dismiss the Towarah Arabs, and taking up our provisions which we had sent on from Suez, we entered into an agreement with the Teyáhah, who, after considerable discussion and futile attempts to extort a large "ghafr" or black mail, engaged to take us anywhere we wished through their country.

Of the various tribes which inhabit the Desert of the Tíh, the most numerous and powerful are the Teyáhah, of whom there are two divisions, the Sagairat and the Benaiyat, and truly they were, as their name implies, "birds of prey." They possess large herds of camels whose numbers are frequently increased by the product of the raids which they make on their hereditary foes the 'Anazeh, whose territory lies around Palmyra and to the east of the Hauran, and is about twenty days' journey from the Tíh. These forays are sometimes carried out on a large scale; on the last occasion the Teyahah numbered I, 000 guns. At times the plunder amounts to many hundred camels, but at others the owners come down in force and the aggressors are compelled to retire. Bloodshed in these freebooting expeditions and even actual warfare is avoided as much as possible, for it results in a blood feud which is always much dreaded by a Bedawi, since it binds the relatives of anyone who has perished either by murder or manslaughter-the Arabs do not distinguish between themto avenge lis death. The blood feud or vendetta thus exercises a most salutary influence, for withont it the value of human life would be totally disregarded in these wild regions which lie beyond the pale of the law.

The Terabín, the tribe next in importance, occupy the country east of the Teyáhah, their territory extending from Jebel Bisher and Bir Abu Suweirah on the Sinai road some forty miles south. east of Suez, as far as Gaza to the north.

The Haiwátt live in the mountains to the west and north-west of Akabah, and are not numerous.

The Azázimeh occupy the mountainous region which I have before mentioned as bearing their name: this tribe is not large, and they are exceedingly poor; their only food consists of the milk and cheese obtained from their camels and goats and such roots as they can dig up. On very rare occasions they may have the luck to shoot some wild animal which, whether it be ibex or hyæna, is equally acceptable to their not over squeamish stomachs. They are obliged to live in very small and scattered communities, from the fact that-with the exception of one or two brackish and unpalateable springs, their only water supply is derived from the rains collected in hollows of rocks in the ravines and wady beds, and even these are few and far between. This water was usually putrid and full of most uninviting animalculæ : however, as no other was to be had, we were obliged to drink it.

From Nakhl we went in a north-easterly direction to Wády Garaiyeh, thence to Jebel 'Araif, which we ascended ; though it is little more than $2,000 \mathrm{ft}$. high; the view is very extensive. We then proceeded to cross Wady Mayín, W. Lussán, and W. Jerúr, and afterwards reached Ain Minweileh (the supposed 
site of Hagar's well). Here are very numerous primeval stone remains, the most remarkable being piles of stones placed in rows at the edges of the cliffs which lace the East. Cannot they be the remains of the old Baal worship followed by the Amorites, whose name is still preserved in the country to the north of W. Muwéileh, at Dheigat el 'Amerín (the ravine of the Amorites), Ras 'Amir, and Sheikh el 'Amiri? At various places on our route, especially at 'Uggábeh_-between Nakhl and W. Garayíeh -..on S. el 'Ejmell, S.'A Araif in Wady Lussán, we found very large numbers of cairns, stone circles with graves, and open spaces, which, to judge from the burnt earth within them, seem to have been designed for sacrificial purposes; also enclosures, girt by rude stone walls ; and, in W. el Biyàr, circular dwellings, some of which are still standing, quite perfect. In W. Rowág nearly every hill is topped by a caim ; there are three on the summit of Jebel Araif, and we noticed that they frequently occurred as far north as Bir Seba and El Milh (Molada).

At Mnwéileh and near a neighbouring spring, Ain Guseimeh, are several caves. At the former place there is one cut in the face of the cliff, and entered by a staircase, ascending from a smaller cave below; this has been at one time the dwelling of a Christian hermit, as we noticed crosses rudely painted in red and traces of frescoes. At this place, too, we found, with the exception of one place in W. Lussán, the first signs of regular cultivation in former times. Stones are laid in lines acioss the wady-beds to check and, at the same time, distribute the drainage, and to prevent the soil being washed down by a suddten seil or flood.

Our next point was El Birein, so called from the two avells in the wady ; here are traces of considerable ruins, a fiskiyeh, or reservoir, and aqueduct, the latter ruined, and the former nearly so. In the wady are some old butmeh or terebinth trees, remarkable as being the first trees, with the exception of two "seyáls" or acacias, that we had seen since leaving Sinai. About six miles $\mathrm{N}^{\top}$. W. of $\mathrm{El}$ Birein lie the ruins of El Aujeh, confounded by Dr. Robinson with 'Abdeh, which I shall presently mention, situated on a low spur running into W. Hanein. This valley, however, on account of a superstition attaching to its real name, has always been called by the Arabs, when speaking to travellers, W. Hafir. Some five or six square miles of the wady are covered with ruined walls of gardens and fields; the sides of the watercourse are built up with large stones, and dams still exist across it, though all the valley is now barren and neglected. Ten miles to the east of $\mathrm{El}$ 'Aujeh we discovered the ruins of a fortress called "El Meshrifeh," perched on a projecting spur, and defended on two sides by steep cliffs, which overlook a broad plain formed by the sweep of Wady el Abyadh as it debouches from Yebel Magrah; the south face of the cliff is fortified by escarpments and towers of massive masonry, and on the summit are ruins of several houses, and of a small church; on the third side a thick wall runs across the level crest of the spur. Beneath the towers and in comnection with them are numerous rock-hewn chambers; also traces of a more ancient and, incleed, primeval wall, and pieces of masonry of a date far anterior to the rest of the buildings.

On the plain above mentioned and three miles and a half to the S.E of El Meshrifeh we found the ruins of a considerable town called S'baita. This name seems to have been heard of by former travellers, who confounded the site with Rehaibeln; but I believe we were the first Europeans to visit the ruins. Here, as in many other cases, we experienced considerable difficulty, owing to the apprehensions of our Bedawin, who did their best to dissuacle us from going there. I succeeded, however, in taking sketches and photographs of the chief points of interest. The town contains three churches, which, like those at El Aujeh el Meshrifeh and $S$ adi, must, I think, be referred to the 5 th century. There are also two reservoirs, and a tower with a rudely ornamented gateway. With the exception of a fragment or two at El Aujeh, this was the only instance of sculpture we saw, and not a single inscription was anywhere to be found.

The structure of the buildings at S'baita is worth hoticing: the upper stories of the houses are supporteit on wide, low-spanned arches two feet wide with intervals of three feet between them and upon these is placed the flooring of the upper rooms, which consists of narrow slabs of stone. Numerous ruined towers and walled gardens and enclosures, extending to a distance of several miles from the town, attest its former importance. The vineyards, too, marked by the "Teleilát el 'Aneb," which I mentioned before, extend over large tracts in this neighbouthood.

From S'baita we went to Rehaibeh, examining en route the ruins of S'adi, * which do not seem to have been visited or even heard of by former travellers. At Rehaibeh the ruins are of much greater extent than at S'adi, but so confused that it is impossible to trace the plan of any single building. There are numerous wells, cisterns, and other remains of cultivation in the neighbourhood. From Rehaibeh we went to Khalasah and Bir Seba : the ruins at the former place have nearly disappearet, as the inhabitants of Gaza find it cheaper to send camels for the already squared stones than to quarry them near their town. Owing to the drought we found Bir Seba barren and deserted, though our Arabs assured us that in good seasons the grass is knee-deep, and furnishes ample pasturage for countless flocks and herds. Our unlooked-for appearance in out-of-the-way districts was usually considered by the natives to be in some manner connected with the exceptional drought, and on several occasions we were either implored to bring rain or cursed for the want of it, since the Arabs furmly believe that every Nasráni holds the weather under his control.

From Bir Seba we went to Jerusalem, and, after a short stay there, retumed to Hebron, where we engaged three of the Jehalin Arabs, with their camels, to convey our baggage to Petra. Taking a new route, we passed Tell Arad and El Milh, and struck into the unexplored mountains of the 'Azázimeh, where we discovered the ruins of the El 'Abdeh (Etoda), which are of considerable extent, and similarly placed to those of $\mathrm{El} \mathrm{Mesh-}$ rifeh, most of the dwellings here, as there, being half excavated and half built. Of the buildings now standing, the greater part are of Christian times. The natives are perfect savages, and detained us for two hours from visiting the ruins by collecting in a gang to the number of thirteen on the top of a pass, singing their war-song, throwing down stones, and occasionally firing off one of their old match-locks in bravado, and swearing by God and the Prophet that no one should come up. As the pass was very narrow, almost precipitous, we judged it best to propitiate them, a task accomplished, after much disctssion, at the cost of eight shillings. They then escorted us to the ruins, where we took such measurements and photographs as we required. From 'Abdeh we went through the 'Azazimeh mountain, a region so awfully desclate as to defy description, struck the 'Arabah at the junction of W. Jerafeh with W. Ghamz, and crossed thence to Petra. Here the Liyathinel fully maintained their character for brutality and insolence. Infidels in all but the name of Moslims, they are descended from the tribe of Khaiberi Jews, who bear such a bad character in Arabia. To add to our discomfort, we were snowed up for two days in a tent only just large enough for us both to lie down in. During a stay of six days, however, Petra was thoroughly examined by us and accurately mapped. We then bent our steps northwards, and at El Barid, about seven miles from Petra, discovered a colony of dwell ings and temples cut in the rock, and some rudely chipped Nabathran inscriptions. The walls and ceilings of the rockchambers were decorated with frescoes, some coarse others well executed. We next travelled down the 'Arabah to the Dead Sex, and having examined the Lisan, went up into Moab. Here we stopped about three weeks and wandered over the country in search of inscriptions, as Mr. Palmer had specially come to ascertain if another Moabite stone was in existence. At last, however, we both came to the conclusion that above srounc there are none. From Moab we crossed the Jordan, near Jericho, and returned to Jertisalem.

(To be continuted.)

\section{SCIENTIFIC SERIALS}

THE fifth part of the nineteenth volume of the Palcontographica recently published, is devoted to the description by Prof. Schenk, of fossil plants from the north German Wealden formation. The plants here described and figured upon 8 plates are all cryptogamous, and with the exception of a single Chara, and four. Equiseto belong to the group of ferns, of which 2 r species are noticed; but it must be remarked that Prof. Schenl bas considerably lessened the apparent number of species by reducing a great many of the names given by former authors to the rank of synonyms. At the same time he describes and figures seven forms as new species, one as the type of a new genus, Marsilidium, belonging to the Rhizocarpex, and he also establishes the new genus Matonidizm for Laccopteris Gopperti, Schimper. The other new species belong to the genera Sphentopteris, Alethoptcris, Laccopteris, Olean-

\footnotetext{
* S'udi is two-and-a-half miles E.S.E. of Rẹaibeh.
} 